\title{
The Effect of Moringa Oleifera Leaf Water Extract on the Number of Ovarian Follicles and the Enzyme Levels of Superoxide Dismutase of Rattus Norvegicus Rats Exposed to Depot Medroxyprogesterone Acetate (DMPA)
}

\author{
Fitri Suryani Hadi ${ }^{1}$, Arni Amir ${ }^{2}$, Desmiwarti ${ }^{3}$, Welda Yulia ${ }^{4}$ \\ ${ }^{1}$ Master's Degree Program of Midwifery, Faculty of Medicine, Andalas University, Indonesia. \\ ${ }^{2}$ Master's Degree Program of Midwifery, Faculty of Medicine, Andalas University, Indonesia. \\ ${ }^{3}$ Master's Degree Program of Midwifery, Faculty of Medicine, Andalas University, Indonesia. \\ ${ }^{4}$ Representatives of the National Family Planning Coordinating Board of West Sumatra Province
}

Corresponding Author: Fitri Suryani Hadi

DOI: https://doi.org/10.52403/ijshr.20220128

\begin{abstract}
Depot Medroxyprogesterone Acetate (DMPA) contraceptives result in reduced release of FSH and LH inhibiting ovarian follicular development and preventing ovulation. Prolonged hypoestrogen causes oxidative stress due to increased ROS. SOD enzymes prevent the formation of ROS. Moringa is a plant that contains high antioxidants and minerals which are cofactors for enzymes that protect against the effects of free radicals by neutralizing them before they damage cells and cause disease. The aims of this study were to determine the effect of Moringa oleifera leaf water extract on the number of ovarian follicles and levels of the enzyme superoxide dismutase in Rattus norvegicus rats exposed to Depo Medroxy Progesterone Acetate.

The study was carried out at the Bukittingi Veterinary Laboratory and the Biomedical Laboratory, Faculty of Medicine, Andalas University, Padang. The study began in April May 2021. The type of study was experimental with a Post Test Only Control Group Design with the number of sample of 30 female rats. The data were analyzed using the Shapiro Wilks normality test. After the parametric test is fulfilled, the hypothesis test is continued using one way ANOVA.

The results of the analysis showed that there was a significant difference between the group
\end{abstract}

k- mean (3.40) $\mathrm{K}+$ mean (1.00) in primary follicles and mean $\mathrm{k}-(3.80)$ and $\mathrm{K}+(1.20)$. In secondary follicles and mean k- (4.20) the mean $\mathrm{k}+(1.40)$ in tertiary follicles and mean $\mathrm{k}-(2.60)$ mean $k+(1.00)$ in Degraaf follicles. The significance value for all types of follicles with ANOVA test with $p$ value $<0.05$. The dose of 300 grams / $\mathrm{kg} /$ body weight per day is the dose that is most able to increase the number of ovarian follicles and SOD enzyme levels in the ovaries with a comparison rate close to the negative control group treatment value.

The conclusion of the study was that administration of Moringa leaf water extract could increase the number of ovarian follicles and levels of the ovarian SOD enzyme in rats exposed to DMPA.

Keywords: DMPA, Ovarian Follicle, SOD, Moringa leaf water extract

\section{INTRODUCTION}

Indonesia, as a developing country, has various types of problems, including in the field of population. In the world, Indonesia is in the fourth place with the largest population after China, India, and the United States. In 2020 (data as of September 2020), Indonesia's population was 270.20 million. This number is an increase of about 32.56 million compared to the 2010 
Fitri Suryani Hadi et.al. The effect of moringa oleifera leaf water extract on the number of ovarian follicles and the enzyme levels of superoxide dismutase of rattus norvegicus rats exposed to depot medroxyprogesterone acetate (DMPA).

population census with a growth ratio population by gender is around 102, which means there are 102 male residents for every 100 female population with details of the male population being 136.66 million people $(50.58 \%)$ and the female population being 133.54 million people $(49.42 \%)^{[1]}$. Efforts to suppress the rate of population growth in Indonesia need to limit births by conducting Family Planning (KB) programs; one of which is the use of contraceptives ${ }^{[2]}$.

West Sumatra Province in 2019 showed the percentage of active family planning participants from the number of couples of childbearing age (PUS) as many as 739,369 people and the most were users of contraceptives using the hormone method or users of Depo Medroxy Progesterone Acetate (DMPA) which was around 268,087 $(62.15 \%)$ person ${ }^{[3]}$. Based on the pattern in the selection of contraceptives, most of the family planning acceptors chose injections and oral as contraceptives, even more than $80 \%$ compared to other methods with the number of injecting family planning participants around $63.7 \%$ of which the oral type was around $17.24 \%$ while the injectable and oral types of family planning included in the short-term contraceptive method so that the level of effectiveness of injections and oral in controlling pregnancy is lower than other types of contraceptives [2].

Depo medroxyprogesterone acetate (DMPA) contraception is a contraceptive in the form of a liquid containing the synthetic hormone progesterone which is injected intramuscularly at a dose of $150 \mathrm{mg}$ into a woman's body periodically every 3 months in the form of micro crystals suspended in aqueous solution in order to prevent pregnancy and is a very effective contraceptive with a very low failure rate but women who use this contraceptive will experience some side effects ${ }^{[4]}$. Side effects of using DMPA injections include menstrual disorders, changes in the frequency and amount of blood lost, weight gain, effects on the cardiovascular system and effects on the reproductive system ${ }^{[5]}$.

DMPA contraceptives containing the hormone Progesterone reduce the frequency of pulsation of Gonadotropin Releasing Hormone $(\mathrm{GnRH})$ produced by the Hypothalamus thereby reducing the release of Follicle Stimulating Hormone (FSH) and Luteinizing Hormone (LH) from the anterior pituitary. Reduction in FSH levels inhibits follicular development thereby preventing an increase in estrogen levels. Progesterone negative feedback and lack of positive estrogen feedback for the release of $\mathrm{LH}$ so that there is no $\mathrm{LH}$ surge for ovulation ${ }^{[6]}$.

Follicular cell development consists of five stages, namely: primary follicle stage, secondary follicle, tertiary follicle, and de Graafian follicle. Estrogen functions as a reproductive hormone and has the ability as an antioxidant. The presence of low estrogen conditions for a long time can cause oxidative stress due to increased Reactive Oxygen Species (ROS) ${ }^{[7]}$. Free radicals or ROS that are produced in excess and are not matched by an increase in the number of antioxidants will cause oxidative stress. Oxidative stress is an imbalance between the production of ROS such as Hydrogen Peroxide (H202) and superoxide radicals. The ability of an organism's natural protective mechanisms that are influenced or determined by endogenous antioxidants and exogenous antioxidants to overcome reactive metabolites and prevent adverse effects ${ }^{[8]}$.

\section{METHODS}

\section{Experimental Animal}

This research is an experimental study with a post test only control group design, which is a design used to measure the effect of treatment on the experimental group by comparing the treatment group with the control group ${ }^{[9]}{ }^{[10]}$. This research was conducted by comparing the experimental group with the control group. The population in this study were female white rats (Rattus Norvegicus). The sample 
Fitri Suryani Hadi et.al. The effect of moringa oleifera leaf water extract on the number of ovarian follicles and the enzyme levels of superoxide dismutase of rattus norvegicus rats exposed to depot medroxyprogesterone acetate (DMPA).

in this study were all populations that met the inclusion and exclusion criteria. The sample size of 30 wistar rats was divided into 5 groups as follows: negative control group (K-) (injected with $0.2 \mathrm{mg}$ aquadest IM on days $1,8,15$, and 22), control group $+(\mathrm{K}+)$ (administered DMPA $2.7 \mathrm{mg}$ IM on days $1,8,15$ and 22), treatment group 1 (P1) (administered DMPA $2.7 \mathrm{mg}$ IM on exposure day 1, 8.15 dn 22 and given the aqueous extract of Moringa leaves 200 $\mathrm{mg} / \mathrm{kg}$ BW/day via sonde on days 1 to 28 ), treatment group 2 (P 2) (administered injection of DMPA $2.7 \mathrm{mg}$ IM on day 1 of exposure, $8.15 \mathrm{dn} 22$ and given Moringa leaf water extract $250 \mathrm{mg} / \mathrm{kg} \mathrm{BW} /$ day via sonde on days 1 to 28) and treatment group 3 (P 3) (administered DMPA $2.7 \mathrm{mg}$ IM injection on day 1 exposure, 8.15 and 22 and given water extract of Moringa leaves $300 \mathrm{mg} / \mathrm{kg} \mathrm{BW} /$ day via sonde on days 1 to 28). This research has carried out an ethical test from the Ethics Committee of the Faculty of Medicine, Andalas University with a certificate No: 335/UN.16.2/KEPFK/2021.

\section{Experimental Animal Care}

The experimental animals used in this study were Rattus Norvegicus wistar or female white rats, aged 10-12 weeks and body weight of 180-200 grams. At the beginning of the experiment, experimental animals were randomized, then adaptation was carried out for one week to adjust to the laboratory environment and relieve stress. During this period, the experimental animals were given standard feed and drank aquabidest ad libitum. After acclimatization, the rats were grouped into 5 groups, namely 2 control groups and 3 treatment groups.

\section{Experimental Animal Care}

Treatment of rats during the treatment was the same as during acclimatization. Rats were put in a cage made of a plastic basin measuring $45 \mathrm{~cm} \mathrm{x}$ $35.5 \mathrm{~cm} \times 14.5 \mathrm{~cm}$ with a strong wire cover. The bottom of the cage was covered with husks $0.5-1 \mathrm{~cm}$ thick and replaced every 3 days. Each cage contains 6 rats. The room light is made for 12 hours of light and 12 hours of darkness, the temperature and humidity of the room are left in the room temperature range of 27-28 oC. Rats were given food and drink ad libitum in the form of water and standard feed in the form of a Comfeed brand pallet with a composition consisting of crude protein, crude fat, calcium and phosphorus. Before administration, the feed is mixed with water until it is evenly distributed so that the consistency is not hard and is done once a day at 16.00 Western Indonesian Time.

\section{Treatment dose \\ DMPA Administration}

DMPA contraceptive with a dose of $150 \mathrm{mg}$ (3 cc) was diluted with $7 \mathrm{cc}$ of distilled water, stirred to make it homogeneous. Then, $0.2 \mathrm{cc}$ containing $3 \mathrm{mg}$ was taken to be injected intra muscularly (IM) in the quadriceps muscle on days 1,8 , 15,22 of treatment, after administration of Moringa leaf water extract. The action of injection using a $1 \mathrm{cc}$ syringe and carried out as aseptic as possible. Pain after injection can be overcome with a slow injection technique. The injection must be done carefully so that complications do not occur because the needle hits a blood vessel. The dose of DMPA used in this study was $3 \mathrm{mg} / \mathrm{rat} /$ week for four weeks ${ }^{\text {[7] [11] [12]. }}$.

\section{Administration of Moringa Leaf Extract}

Rats were weighed once per week using a digital scale. The recording of body weight is averaged as a guide for giving Moringa leaf water extract. If the weight of the rats on average is 200 grams, then the need for Moringa leaf water extract for each treatment group is as follows with the formula: Administration dose $=$ desired dose/kg body weight

1. For treatment group 1 (dose of $200 \mathrm{mg}$ ) $200 \mathrm{mg} / 1000=0.2 \mathrm{grams} / \mathrm{rat}$ so for 6 rats $(0.2$ grams $\times 6)=1.2$ grams $\times 28$ days $=33.3$ grams

2. For treatment group 2 (dose of $250 \mathrm{mg}$ ) 
Fitri Suryani Hadi et.al. The effect of moringa oleifera leaf water extract on the number of ovarian follicles and the enzyme levels of superoxide dismutase of rattus norvegicus rats exposed to depot medroxyprogesterone acetate (DMPA).

$250 \mathrm{mg} / 1000=0,25 \mathrm{gram} / \mathrm{rat}$ so for 6 rats $(0,25$ gram $\times 6)=1,5$ gram $\times 28$ days $=42$ grams

3. For treatment group 3 (dose of $300 \mathrm{mg}$ ) $300 \mathrm{mg} / 1000=0,3 \mathrm{gram} / \mathrm{rat}$ so for 6 rats $(0,3$ gram x 6$)=50,4$ grams

\section{Measurement of SOD Level.}

SOD levels were measured by ELISA method using Total superoxide dismutase (T-SOD) activity assay kit (WST - 1 Method) brand ELBACIENCE with catalog number Cat.No: E- BC- K020- M size $97 \mathrm{~T}$ with the following steps (Elabscience Biochemical Assay Kit).

\section{Ovarian Histology Preparation Making}

At the beginning of the process of making histology preparations for necropsied animals, the ovaries were taken and then fixed in $10 \%$ BNF solution for 2448 hours.

\section{Observation and Counting the Number of Follicles \\ Observation of Ovarian Histology Preparations}

Observations were made by examining the ovaries of 30 female rats which were made as a result of histology preparations using hematoxylin-eosin staining, which is a dual function stain. The first function allows the recognition of certain tissue components by differentially staining them while the second function is to be able to color with or to different degrees of color resulting in different depths. In the Hematoxylin Eosin staining, the hematoxylin dye complex is dark purple in color while the eosin dye gives a pink to red color to the tissue components that are not stained blue purple by hemaktocillin which functions as an alkaline and basophilic dye and the acidic and acidophilic eosin dye in the tissue ${ }^{[13]}$. Staining histology preparations can be done by using an autostainer, which is an automatic tool for staining histology preparations or manually, with several stages of immersion into a solution in a staining jar solution.
The purpose of histology of hematoxylin Eosin staining is to determine the presence or absence of abnormal cell morphology in the tissue examined. The principle of histology staining is hematoxylin eosin chromatin in the cell nucleus will bind to alkaline paint (hematoxylin) and cytoplasmic proteins will bind acidic paint (eosin) so that the cell will be pink with a purplish nucleus ${ }^{[13]}$.

\section{Calculation of Preparations for the Number of Ovarian Follicles}

Calculations were carried out in four fields of view and each number of follicles was counted under the supervision of a biologist using a binocular microscope. Data collection was done by counting the number of primary, secondary, tertiary and De Graff follicles in a semi-qualitative way.

\section{Data Analysis}

Data from the results of the normality test was carried out by using the Shapiro Wilk test $(\mathrm{n}<30)$. The data is said to be normally distributed if the $\mathrm{p}$ value $>$ 0.05 . The $\mathrm{p}$ value $<0.05$ indicates that the data is not normally distributed and not homogeneous, so parametric statistical tests cannot be used, and the analysis is continued with non-parametric statistical tests. If a normal data distribution is obtained, then a One way Anova parametric statistical difference test is carried out with a $95 \%$ confidence degree $(\alpha=5 \%)$. If there is a significant difference, then it is continued with the Bonferroni or LSD Multiple Comparison (Pos Hoc Test) statistic to see the significance between the groups with Post Hoc Mann Whitney test [10].

\section{RESULTS \\ Effect of depo medroxyprogesterone acetate on the number of primary, secondary, tertiary ovarian follicles of Rattus norvegicus rats}

From the results of data processing on the calculation of the number of primary ovarian follicles on the research on the 
Fitri Suryani Hadi et.al. The effect of moringa oleifera leaf water extract on the number of ovarian follicles and the enzyme levels of superoxide dismutase of rattus norvegicus rats exposed to depot medroxyprogesterone acetate (DMPA).

effect of Moringa leaf water extract on the number of ovarian follicles of Rattus Norvegicus rats exposed to Depo Medroxy Progesterone Acetate. The difference in the mean number of primary, secondary and tertiary follicles in the five sample groups is presented in the form of Figures 1,2 and 3 in the Histogram graph below:

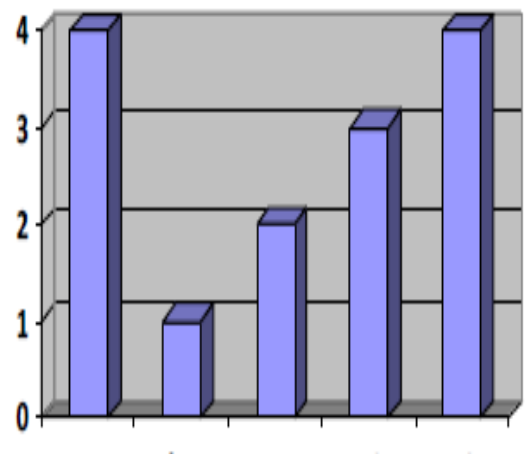

DP.PRIMER

\section{K. $\quad k+\quad P 1 \quad P 2 \quad P 3$}

Figure 1. Graph of Average Number of Primary Ovarian Follicles of Rattus Norvegicus Rats Exposed to Depo Medroxy Progesterone Acetate

The results of the Pos Hoc Bonferroni test proved that by giving Moringa leaf water extract to the number of primary follicles of Rattus Norvegicus Ovary there was a significant difference between the negative control group and the positive control group with $\mathrm{p}$ value $=0.001$ $(\mathrm{p}<0.05)$ and treatment 1 with $\mathrm{p}$ value $=$ 0.033 . Positive control group with treatment 3 that is equal to $p$ value $=0.002$ and treatment group 1 with negative control group that is $\mathrm{p}$ value $=0.033$ and treatment 3 of the positive control group that is equal to $p$ value $=0.002$

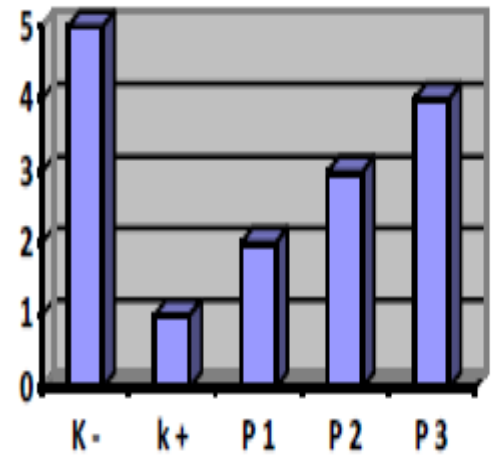

\section{DSEKUNDER}

Figure 2. Graph of the average number of secondary follicles of Rattus Norvegicus Ovaries exposed to Depo Medroxy Progesterone Acetate
The results showed that by giving Moringa leaf water extract to the number of secondary follicles of Rattus Norvegicus Ovary there was a significant difference between the negative control group and the positive control group with a $\mathrm{p}$ value of 0.02 and treatment 1 with a $\mathrm{p}$ value of 0.04 . Positive control group with treatment 2 with $\mathrm{p}$ value 0.40 and treatment 3 with $\mathrm{p}$ value 0.007 and treatment group 1 with negative control group with $\mathrm{p}$ value 0.040 and treatment 2 with positive control with $p$ value 0.040 and treatment 3 towards positive control group with a $\mathrm{p}$ value of 0.007 .

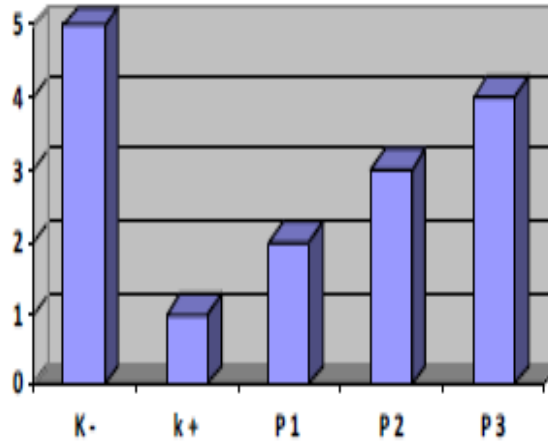

口TERSIER

Figure 3. Graph of Average Number of Tertiary Follicle Ovarian Rattus Norvegicus Rats Exposed to Depo Medroxy Progesterone Acetate in Control and Treatment Groups

The results can be seen that by giving Moringa leaf water extract to the number of tertiary follicles of Rattus Norvegicus ovary there is a significant difference between the negative control group and the positive control group with a $\mathrm{p}$ value of 0.002 and a positive control of treatment 2 with a $\mathrm{p}$ value of 0.033 and treatment 3 with p-value 0.006. Treatment group 3 on positive control has $\mathrm{p}$ value of 0.006 .

The effect of depo medroxy progesterone acetate on the number of ovarian degraff follicles in Rattus norvegicus rats

From the results of data processing on the calculation of the number of ovarian Degraff follicles on the study, it can be seen that the effect of giving Moringa leaf water extract on the number of ovarian follicles of Rattus Norvegicus rats exposed to Depo 
Fitri Suryani Hadi et.al. The effect of moringa oleifera leaf water extract on the number of ovarian follicles and the enzyme levels of superoxide dismutase of rattus norvegicus rats exposed to depot medroxyprogesterone acetate (DMPA).

Medroxy Progesterone Acetate, it can be seen that the average number of Deg raff follicles in the K-group looks different from the $\mathrm{K}+$ group. The difference is about 1.60 . The $\mathrm{K}+$ group had the lowest mean number of De Graff follicles among the other groups, which was around 1.00. The group that has a value close to the $\mathrm{K}$ - group is treatment group 3 which is around 2.08. The difference in the mean number of De Graff follicles in the five sample groups is presented in the form of 4 Histogram graphs below:

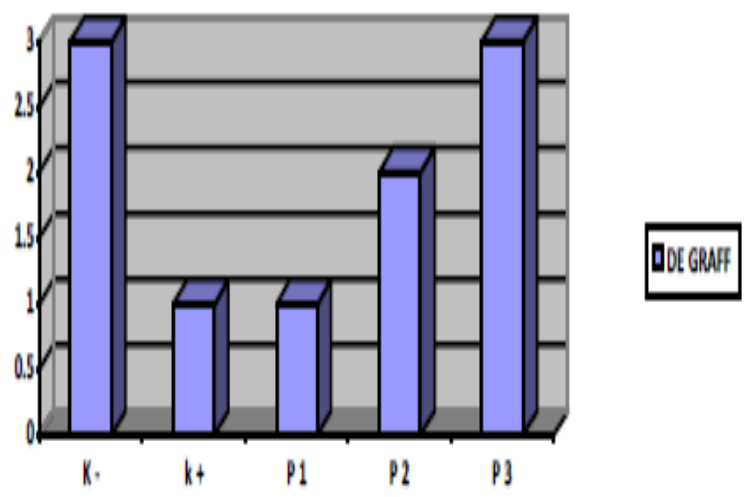

Figure 4. Graph of the Average Number of De Graff Ovarian Follicles of Rattus Norvegicus Rats Exposed to Depo Medroxy Progesterone Acetate

The results of data processing can be seen that by giving Moringa leaf water extract to the number of follicles of De Graff Ovarium Rattus Norvegicus there is a significant difference between the negative control group and the positive control group with $\mathrm{p}$ value 0.010 and positive control with treatment 3 with $\mathrm{p}$ value 0.002 and treatment 1 with treatment 3 with a $p$ value of 0.047 and treatment 3 with a positive control with a $\mathrm{p}$ value of 0.002 and treatment 1 with a $p$ value of 0.047 .

\section{The effect of depo medroxy progesterone acetate on SOD levels of Rattus Norvegicus Ovarian Rats}

Ovarian SOD levels were measured by using Total Superoxide Dismutase (T SOD) Activity Assay Kit (WST-1 Method) with catalog number No: E-BC-K020-M with Colorimetric method, specification 96T with sensitivity $0.2 \mathrm{u} / \mathrm{ml}$. The results reveal that the mean SOD levels in the $\mathrm{K}$ - group look different from the $\mathrm{K}+$ group. The difference is about 2.26 . The $\mathrm{K}+$ group has the lowest mean SOD level among the other groups, which is around 16.71. The group that has a value close to the $\mathrm{K}$ - group is treatment group 3 which is around 18.86. The significance value shows $\mathrm{p}$ value $<0.05$ which can be interpreted that there is a significant difference in SOD levels between the control group and the treatment group by giving Moringa leaf water extract exposed to DMPA. The increase in SOD levels in the treatment group compared to the positive control group means that exposure to Moringa leaf water extract can increase SOD levels in the ovaries. The difference in the mean levels of SOD in the five sample groups is presented in the form of a Histogram graph below:

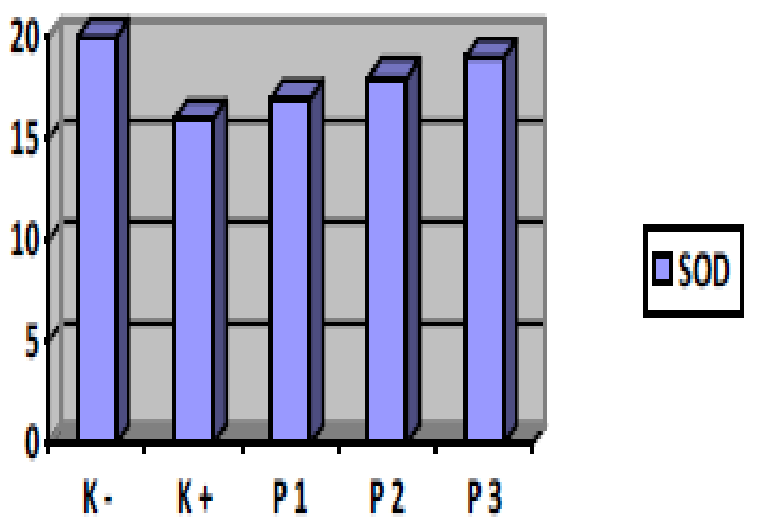

Figure 5. Graph of Average Levels of Ovarian Superoxide Dismutase Enzyme Rattus Norvegicus Exposed to Depo Medroxy Progesterone Acetate in Control and Treatment Groups

The results of data processing can be seen that by giving Moringa leaf water extract to the SOD levels of Rattus Norvegicus Ovaries there is a significant difference between the negative control group and the positive control group with a $\mathrm{p}$ value of 0.000 and treatment 1 with $\mathrm{a} p$ value of 0.000 . Positive control group with treatment 1 with $\mathrm{p}$ value 0.000 and treatment 2 with $\mathrm{p}$ value 0.001 and treatment 3 with $\mathrm{p}$ value 0.000 . Treatment group 1 with a negative control group had a p-value of 0.000 and treatment 3 had a pvalue of 0.000 and treatment 2 with a 
Fitri Suryani Hadi et.al. The effect of moringa oleifera leaf water extract on the number of ovarian follicles and the enzyme levels of superoxide dismutase of rattus norvegicus rats exposed to depot medroxyprogesterone acetate (DMPA).

positive control had a p-value of 0.001 and treatment group 3 with a positive control group had a p-value of 0.000 and treatment 1 had a p-value 0.000 .

\section{DISCUSSION}

\section{Effect of Moringa Leaf Water Extract (Moringa Oleifera) on the number of Degraff Ovarian Follicles Rattus Norvegicus exposed to Depo Medroxy Progesterone Acetate.}

Based on the results of the data interpretation, the significance value of the effect of Moringa leaf water extract on the number of De Graff follicles is $p$ value of 0.021 ; it means that there is a significant difference between the sample groups also seen between the negative control group and the positive control group based on the mean value of the positive control group which is smaller than the negative control group. This means that DMPA exposure can reduce the number of Degraff follicles in the ovaries.

The results of data processing also show that there is no significant difference in the number of De Graff follicles between the positive control group and the treatment with DMPA + Moringa leaf water extract $200 \mathrm{mg} / 250 \mathrm{~kg} /$ day or P 1 and P II, but the mean value of the number of De Graff follicles appearing in the treatment group has a higher value than the positive control group, which means that there is an increase in the number of Degraff follicles due to the treatment with Moringa leaf water extract, although the increase is not statistically significant.

Likewise, there is a significant difference in the mean number of follicles between the positive control group than the group receiving DMPA + Moringa leaf water extract $300 \mathrm{mg} / \mathrm{Kb} / \mathrm{BW} /$ day. It reveals that the mean value of the number of Degraff follicles in treatment 3 is close to the mean number of the negative control group. This proves that the administration of Moringa leaf water extract can increase the number of ovarian follicles of rats exposed to DMPA where a dose of 300 $\mathrm{mg} / \mathrm{Kb} / \mathrm{BW} /$ day is the dose most capable of increasing the number of De Graff follicles.

This shows that most of the significant effect by administering Moringa leaf water extract to all the number of ovarian follicles which can be seen from the mean value of the number of follicles in the treatment group is greater than the positive control group although the increase is not statistically significant.

The development of ovarian follicles is influenced by the hormone estrogen produced by the theca interna cells from the ovarian follicle and the development and maturation of follicles and estrogen secretion is controlled by the hormone GnRH. GnRH hormones from the pituitary include FSH and LH hormones which function for the process of folliculogenesis and ovulation ${ }^{[14]}$. The secretion of estrogen into the follicle causes the granulosa cells to form more and more FSH receptors, causing a positive feedback effect on FSH secreted by the anterior pituitary gland. An increase in the number of estrogen and follicles and an increase in LH from the anterior pituitary gland work together to cause the proliferation of follicular theca cells and also increase follicular secretion ${ }^{[15]}$.

Administering

DMPA Contraceptives to family planning acceptors will inhibit follicular development and prevent ovulation. Progesterone present in DMPA reduces the frequency of $\mathrm{GnRH}$ pulses produced by the hypothalamus thereby reducing the release of FSH and LH from the anterior pituitary. Reduction in FSH levels inhibits follicular development thereby preventing an increase in estrogen levels. Progesterone negative feedback and lack of positive feedback estrogen to release LH prevent the LH surge to occur for ovulation events ${ }^{[16]}$.

Based on the research that has been done by Desi Amelia (2017) about the effect of Moringa leaf extract (Moringa Oleifera) on the number of follicles of the Polycystic Ovarian Syndrome (SOPK) rat model, the results showed that the group given metformin and Moringa oleifera leaf extract 
Fitri Suryani Hadi et.al. The effect of moringa oleifera leaf water extract on the number of ovarian follicles and the enzyme levels of superoxide dismutase of rattus norvegicus rats exposed to depot medroxyprogesterone acetate (DMPA).

showed a significant increase in the number of follicles were compared with the PCOSinsulin resistance control group with a value $(\mathrm{p}<0.05)$. The conclusion of the study showed that Moringa oleifera leaf extract increased the number of follicles in female rats model of PCOS-insulin resistance ${ }^{[17]}$.

In line with the research conducted by Balumbi et al (2021) on Ovarian Morphometry after administration of Moringa leaf extract, the results showed that the level of concentration and duration of administration of Moringa leaf extract had an effect on the length, width, and weight of the rats ovaries. This study took about 34 days of treatment with a dose of P1 200, P2 300 and P3 500 in the review stated that one of the most prominent which is thought to have a large effect on ovarian size and weight from the content of Moringa leaves is high flavonoids. In plants, flavonoids have a very important function in supporting the process of photosynthesis, antimicrobial, and antiviral. Flavonoids are a group of isoflavone compounds that can bind directly to estrogen receptors, because they have a chemical structure similar to 17$\alpha$ estradiol in the body ${ }^{[18]}$.

Another prominent content in Moringa leaf extract is steroids. Steroids belong to the phytosterol group that cannot bind directly to the estrogen receptor, so they need to be synthesized again with the help of certain enzymes produced by mitochondria and smooth endoplasmic reticulum to obtain a chemical structure similar to $17-\alpha$ estradiol. The content of flavonoids and steroids contained in Moringa leaf extract is part of the phytoestrogens which have almost the same activity as the endogenous estrogen hormone so that it is able to recognize and bind to estrogen receptors in body organs located in the nuclear membrane and plasma membrane. Estrogen receptors in the body are divided into two types, namely estrogen receptors alpha (ER- $\alpha)$ and estrogen receptors beta (ER- $\beta)$. ER- $\alpha$ is found in a number of target organs, one of which is the ovaries and uterus, while ER- $\beta$ is found in the ovaries, hypothalamus, lungs, and kidneys. The intake of phytoestrogen compounds from Moringa leaf extract in rats is thought to help fill the void of estrogen receptors that have not yet bound to estrogen in the body, so that estrogen levels in the blood increase and stimulate the hypothalamus to secrete GnRH so that the anterior pituitary secretes more FSH hormone to stimulate primary follicles to become de Graff. In addition, high levels of estrogen in the blood cause a surge of LH in the blood; this condition causes the proliferation of cells in the ovaries, causing the size and weight of the ovaries to increase ${ }^{[18]}$.

Based on research that has been done by Ria Rindi Atina et al(2017). Regarding the ethanolic extract of Moringa Oleifera Lam on folliculogenesis in endometriosis model rats, the results showed that there was a significant difference $(p<0.05)$ in the number of primary, secondary, tertiary and De Graff follicles in the control group and the treatment group with a dose of 0,35 $\mathrm{mg} / \mathrm{gBW}$. The conclusion of the study showed that the ethanol extract of Moringa leaves increased folliculogenesis in endometriosis model rats ${ }^{[19]}$.

In general, the results of this study support the results of previous research studies and confirm that Moringa is a food source that is rich in antioxidant content. Moringa is very good for consumption by the community, especially for acceptors, especially DMPA contraception because it can increase the number of follicles which will reduce the side effects of using DMPA contraception.

\section{Effect of Moringa Leaf Water Extract (Moringa Oleifera) on Levels of Superoxide Dismutase Enzyme in Rats (Rattus Norvegicus) exposed to Depo Medroxy Progesterone Acetate}

From the results of the Pos Hoc Bonferroni test in this study, it is found that ovarian SOD levels were examined and there was a significant difference between 
Fitri Suryani Hadi et.al. The effect of moringa oleifera leaf water extract on the number of ovarian follicles and the enzyme levels of superoxide dismutase of rattus norvegicus rats exposed to depot medroxyprogesterone acetate (DMPA).

SOD levels in the negative control group and the positive control group. Viewed from the average, the positive control group has a smaller mean value than the negative control group. This shows the effect of DMPA exposure on ovarian SOD levels can reduce ovarian SOD levels.

The results of the study obtained can be seen in Histogram Figure 5.9. A significant difference between the sample groups is also seen between the negative control group and the positive control group based on the mean value of the positive control group. The mean value of the positive control group is smaller than the negative control group; this means that DMPA exposure can reduce the level of SOD in the ovaries.

The results of data processing also showed that there was a significant difference in the mean SOD levels between the positive control group and the treatment with DMPA + Moringa leaf water extract $200 \mathrm{mg} / \mathrm{kg} /$ day or P1. The mean value of SOD levels in the treatment group was greater than the positive control group. which means that there is an increase in SOD levels due to the treatment of giving Moringa leaf water extract which has been previously exposed to DMPA with a $\mathrm{p}$ value $<0.05$ which is 0.000 .

Furthermore, there was a significant difference in the mean SOD levels between the positive groups compared to the group given DMPA + Moringa leaf water extract $250 \mathrm{mg} / \mathrm{Kb} / \mathrm{BW} /$ day. The mean value of SOD levels in the treatment group was greater when compared to the positive control group which means that there is an increase in SOD levels with treatment to rats that have previously been exposed to DMPA also with a $p$ value $<0.05$, which is 0.001 .

Likewise, there was a significant difference in the mean SOD levels between the positive control group compared to the group receiving DMPA + Moringa leaf water extract $300 \mathrm{mg} / \mathrm{Kb} / \mathrm{BW} /$ day. It appears that the mean value of SOD levels in treatment 3 is close to the mean of the negative control group. This proves that the administration of Moringa leaf water extract can increase the Ovarian SOD levels of rats exposed to DMPA where the dose of 300 $\mathrm{mg} / \mathrm{Kb} / \mathrm{BW} /$ day is the dose that is most capable of increasing SOD levels with $p$ value $<0.05$, which is 0.000 .

SOD enzyme is one of the enzymatic antioxidants that acts as the first and main intracellular antioxidant against the effects of free radicals. Free radicals are a byproduct of normal metabolic processes called Reactive Oxygen Species (ROS) and integrated reactive nitrogen compounds (SNR). The production of ROS can disrupt homeostasis or stimulate cell growth, depending on the amount of ROS produced in our body. However, when ROS production exceeds antioxidant capacity, it leads cells to oxidative stress ${ }^{[20]}$.

Hypoestrogen conditions due to DMPA exposure can increase ovarian oxidative changes that can cause lipid peroxidation. The mechanism of action of DMPA in inhibiting ovulation causes the production of estrogen to decrease so that the use of DMPA for a long time can cause the body to experience hypoestrogen. This condition can indirectly increase free radicals and cause a decrease in antioxidant enzymes such as SOD and GPX. This is often associated with the role of estrogen as an antioxidant, where in physiological concentrations, estrogen acts as a strong antioxidant in the body ${ }^{[21]}$.

Research done by Bonou Lamou, et al (2016) by conducting trials on wistar rats by giving Moringa leaf water extract with various doses for 28 days after which a forced swimming test was carried out on 8 rats from each group that were given a load of $10 \%$ per kilogram of body weight in rats and the rest were told to swim freely. Afterwards, swimming performance was measured and the biochemical parameters concluded that Moringa leaf water extract can improve swimming performance and increase the activity of antioxidant enzymes such as SOD, GPX and CAT with $p$ value of $<0.05^{[22]}$. 
Fitri Suryani Hadi et.al. The effect of moringa oleifera leaf water extract on the number of ovarian follicles and the enzyme levels of superoxide dismutase of rattus norvegicus rats exposed to depot medroxyprogesterone acetate (DMPA).

The results of the SOD examination in the negative control group, positive control and 3 DMPA exposure treatment groups + Moringa leaf water extract at a dose of $200 \mathrm{mg} / \mathrm{Kg} / \mathrm{BW} /$ day, $\quad 250$ $\mathrm{mg} / \mathrm{Kg} / \mathrm{BW} /$ day and $300 \mathrm{mg} / \mathrm{Kg} / \mathrm{BW} /$ day showed that The mean SOD level increased with the increase in the dose of Moringa leaf water extract. The highest mean value of SOD levels was found in the treatment group giving Moringa leaf water extract at a dose of $300 \mathrm{mg} / \mathrm{Kg} / \mathrm{BW} /$ day so it can be concluded that the most effective dose in increasing SOD levels compared to other doses.

According to the research statement conducted by Setiasih (2020) on Moringa leaf extract given orally at a dose of 300 $\mathrm{mg} / \mathrm{kg} /$ body weight/day, it is stated that this dose is the most widely reported by other publications which is very effective for treating organ toxicity, in the results of his research which aims to examine the possible impact Moringa leaf extract improved against MTX-induced changes in rat spleen oxidative stress with the result that Moringa leaf extract effectively affected changes in total protein, spleen MDA, SOD and CAT activity with $\mathrm{p}$ value $<0.05^{[23]}$.

Moringa is a plant that is rich in antioxidants and other important nutrients needed by the body. Antioxidants are substances or compounds that are able to slow down or prevent the oxidation process, protect biological systems and counter the potential effects of processes or reactions that cause excessive oxidation. SOD, CAT and GPx are enzymes that are part of the body's defense mechanism against ROS ${ }^{[24]}$.

Flavonoid is the most abundant polyphenol component in fruit and vegetable. The flavonoid contained in the aqueous extract of Moringa leaves acts as antioxidants because of their ability to bind to ROS directly by donating hydrogen atoms so as to prevent lipid peroxidation and further help maintain membrane integrity ${ }^{[25]}$. In accordance with the research that has been done by Susanti et al (2020) on Antioxidant Activity of Moringa
Leaf Extract (Moringa oleifera) as an Additive for Making Moisturizers, this study aims to obtain Moringa leaf extract through maceration extraction methods and make a moisturizer (moisturizer) with the addition of Moringa leaf extract because Moringa leaves contain flavonoid active compounds that function as antioxidants to help neutralize and stabilize free radicals so that they no longer damage cells and healthy tissues. This study is conducted to calculate the levels of flavonoids contained in the extract showing that Moringa leaf extract has very high antioxidant activity ${ }^{[26]}$.

Based on research that has been done by Agustiana Dwi Indiah Ventiyaningsih(2020) on the Effect of Moringa Oleifera Leaves Powder to Level of Serum Superoxide Dismutase (SOD), Lead $(\mathrm{Pb})$, Zink (Zn) and Memory Function of Rat (Rattus norvegicus) Wistar Strain Model of Autism that is Exposed by $\mathrm{Pb}$, with final conclusion from the study, it was found that there was a significance between the positive control group with treatments 2 and 3 with a $\mathrm{p}$ value $<0.05$, which means that Moringa leaf powder increased serum SOD levels in autistic rats ${ }^{[27]}$. In line with research by Hala Abdelazem Mostafa(2019) on the Effect of Moringa oleifera on antioxidant enzymes and oxidative stress induced by aluminum exposure in male albino rat testes, the results showed that moringa oleifera had a corrective effect on antioxidant enzyme activity and oxidative stress induced by aluminum exposure in the testes of male albino rats ${ }^{[28]}$.

This is also in line with the research conducted by Tarfa Albrahim (2018) on the Roles of Moringa oleifera Leaf Extract in Improving the Impact of High Dietary Intake of Monosodium Glutamate-Induced Liver Toxicity, Oxidative Stress, Genotoxicity, DNA Damage, and PCNA Alterations in Male Rats with the results of the study obtained significant results with a $\mathrm{p}$ value $<0.05$ between the group given monosodium glutamate and moringa oleifera ${ }^{[29]}$. 
Fitri Suryani Hadi et.al. The effect of moringa oleifera leaf water extract on the number of ovarian follicles and the enzyme levels of superoxide dismutase of rattus norvegicus rats exposed to depot medroxyprogesterone acetate (DMPA).

Based on several studies that have been mentioned above, there is agreement with the results of this study. Free radicals caused by long-term use of DMPA will affect the oxidant defense system in the body which is not balanced with oxidants that arise which will trigger various diseases. Oxidative stress is implicated in human disease ${ }^{[30]}$. In general, the results of this study strengthen the results of previous research studies and confirm that Moringa is a food source that is rich in antioxidant content. Moringa is very well consumed by the community, especially for acceptors, especially DMPA contraception because it can increase levels of the enzyme Superoxide Dismutase which will reduce the side effects of using DMPA contraceptives.

\section{Implications of Research Results in Midwifery}

The use of contraception is an effort programmed by the National Family Planning Coordinating Board (BKKBN) to regulate the spacing of pregnancies in order to realize the creation of a quality family. Midwives are a profession that is at the forefront of realizing the success of the program, considering that the installation of contraceptives is one of the main authorities of midwives as stipulated in Law No. 4 of 2020 concerning Midwifery ${ }^{[3]}$.

This study evaluates the side effects of using DMPA 4 times (if converted to humans for 1 year) can reduce SOD levels and states that the largest proportion of DMPA acceptors with a duration of use of one year is $80 \%$, therefore midwives must provide health education or education to prospective family planning acceptors and those who have become DMPA contraceptive acceptors about the side effects that may be caused by the use of DMPA contraceptives and how to overcome these side effects by consuming this Moringa leaf ${ }^{[11]}$.

\section{CONCLUSION}

The conclusions of the present research are as follows:

1. The administration of Moringa leaf water extract at a dose of 300 $\mathrm{mg} / \mathrm{Kg} / \mathrm{Bb} /$ day has an effect on the number of primary ovarian follicles of Rattus norvegicus rats on the number of ovarian follicles in the group that was given DMPA alone with a $\mathrm{p}$ value of 0.002

2. The administration of Moringa leaf water extract at a dose of 300 $\mathrm{mg} / \mathrm{Kg} / \mathrm{Bb} /$ day has an effect on the number of secondary ovarian follicles of Rattus norvegicus rats on the number of ovarian follicles in the group given DMPA alone with a $\mathrm{p}$ value of 0.007

3. The administration of Moringa leaf water extract at a dose of $300 \mathrm{mg} / \mathrm{Kg} / \mathrm{Bb} /$ day has an effect on the number of tertiary ovarian follicles of Rattus norvegicus rats on the number of ovarian follicles in the group given DMPA alone with a $\mathrm{p}$ value of 0.006

4. The administration of Moringa leaf water extract at a dose of $300 \mathrm{mg} / \mathrm{Kg} / \mathrm{Bb} /$ day has an effect on the number of ovarian Degraff follicles in Rattus norvegicus rats on the number of ovarian follicles in the group given DMPA alone with a $\mathrm{p}$ value of 0.002 .

5. The administration of Moringa leaf water extract at a dose of 200 $\mathrm{mg} / \mathrm{Kg} / \mathrm{Bb} /$ day and a dose of $300 \mathrm{mg} / \mathrm{Kg} / \mathrm{Bb} /$ day has an effect on the levels of the superoxide dismutase enzyme in the ovaries of Rattus norvegicus rats on the superoxide dismutase enzyme levels in the group given DMPA injection alone with a value of $p$ Value 0.00

Acknowledgement: None

Conflict of Interest: None

Source of Funding: None

Ethical Approval: Approved 
Fitri Suryani Hadi et.al. The effect of moringa oleifera leaf water extract on the number of ovarian follicles and the enzyme levels of superoxide dismutase of rattus norvegicus rats exposed to depot medroxyprogesterone acetate (DMPA).

\section{REFERENCES}

1. BPS, "Statistik Indonesia 2021," 2021.

2. Kemenkes, Profil Kesehatan Indonesia Tahun 2018. Jakarta : Kemenkes RI, 2019.

3. Perwakilan BKKBN Sumbar, "Pendataan Keluarga," 2020.

4. Syaifuddin, Buku panduan praktis pelayanan kontasepsi. Jakarta: Yayasan Bina Pustaka Sarwono Prawiro Rahardjo, 2006.

5. Handayani, Buku Ajar Keluarga Berencana. Yogyakarta: Pustaka Rihama, 2010.

6. G. Krikun and Et.all, "long term progestin contaseptives induce aberaant angiogenesis oxidatif stres and apoptosis," Angiogenes. reseach, vol. 2, pp. 1-7, 2010.

7. N. Veri, "Pengaruh ekstrak teh hijau terhadap ekpresi eNos dan indeks apoptosis endometrium rattus norvegikus yang dipapar DMPA," J. Fam. Reprod., vol. 7, p. 109, 2015.

8. Goldberg, "Obesity and Contraception Controversy," Hindawi, pp. 1-8, 2012.

9. Notoadmodjo, Motodologi Penelitian. Jakarta : Rineka Cipta, 2010.

10. A. Rianto, Pengolahan dan analisis data kesehatan. Yogyakarta: Nuha Medika, 2020.

11. Jayanti, "Pengaruh ekstrak air daun kelor( moringa oleifera ) terhadap kadar sod dan indeks apoptosis ovarium tikus wistar yang di papar depo mendroxy progesteron asetat," Kedokt. Univ. Brawijaya, 2017.

12. S. W. Nur'aini, "Pengaruh ekstrak air daun kelor terhadap kadar leptin dan malondialdehyde lemak visceral tikus wistar yang dipapar Depo medroxy progesteron acetat," J. issues midwifery, pp. 38-44, 2018.

13. D. Putra, "Identifikasi senyawa kimia ekstrak etanol daun kelor ( moringa oleifera)," Med. Veternus, vol. 5, pp. 465466, 2016.

14. N. A. Pramesti, "Pengaruh pemberian ekstrak kedelai terhadap jumlah pertumbuhan folikel ovarium mencit," Med. Vet., pp. 120-127, 2018.

15. F. Cunningham et al, Obstetri Williams. Jakarta :EGC, 2014.
16. Speroff, Clinical Gynecologic Endocrinology and infertility. Jakarta: EGC, 2014.

17. Desi et al, "Effects of Moringa Oleifera on Insulin Levels and Folliculogenesis in Polycystic Ovary Syndrome Model with Insulin Resistance," Betham Sci., pp. 2230, 2017.

18. M. Balumbi, "Morfometri Ovarium setelah Pemberian Ekstrak Daun Kelor (Moringa oleifera LAM)," Acta Vet. Indones., pp. 44-52, 2021.

19. Antina, "Ekstrak Etanol Moringa Oleifera Lam Terhadap Folikulogenesis Pada Mencitmodel Endometriosis," Biosains Pascasarj., pp. 246-261, 2017.

20. E. Simanjuntak, "Superoksida Dismutase (Sod) Dan Radikal Bebas," $J$. Keperawatan dan Fisioter., pp. 124-129, 2020.

21. E. S. Wahyuni, Kontrasepsi Hormonal Progesteron. Surakarta: Pustaka Hanif, 2017.

22. B. Lamou, "Antioxidant and antifatique properties of the Aqueos ekstract of moringa oleifera in rat subjected to forced swimming endurance test," Hindawi, pp. 1-9, 2016.

23. Setiasih, "Pengaruh Pemberian Ekstrak Daun Kelor (Moringa Oleifera, Lam) Terhadap Kesiapan Kawin Dan Perkembangan Folikel Ovarium Kelinci," Gontor Agrotech Sci., pp. 1-14, 2020.

24. X. Y. YangLiu, "Value,properties and utility of different part of moringa oleifera An Overview," Chinese Herb. medichines, vol. 10, pp. 371-378, 2018.

25. P. Sujatha, "Moringa oleifera Natures Gold," Imp. J. Interdiscip. Res., pp. 11751177, 2017.

26. Susanti et.al, "Aktivitas Antioksidan Ekstrak Daun Kelor (Moringa oleifera) Sebagai Zat Tambahan Pembuatan Moisturizer," jurnal.umj.ac.id/index.php/semnastek, pp. 1-7, 2019.

27. A. D. Vetiyaningsih, "The Effect of Moringa Oleifera Leaves Powder to Level of Serum SuperoxideDismutase (SOD), Lead $(\mathrm{Pb})$, Zink ( $\mathrm{Zn})$ and Memory Function of Rat (Rattus norvegicus) Wistar Strain Model of Autism that is 
Fitri Suryani Hadi et.al. The effect of moringa oleifera leaf water extract on the number of ovarian follicles and the enzyme levels of superoxide dismutase of rattus norvegicus rats exposed to depot medroxyprogesterone acetate (DMPA).

Exposed by Pb," Res. J. Life Sci., pp. 5261, 2020.

28. H. A. Mustofa, "Effect of Moringa oleifera on antioxidant enzymes and oxidative stress induced by aluminium exposure in male albino rat testes," Int. $J$ Cancer Biomed. Res., pp. 34-41, 2019.

29. Binobead, "Roles of Moringa oleifera Leaf Extract in Improving the Impact of High Dietary Intake of Monosodium Glutamate-Induced Liver Toxicity, Oxidative Stress, Genotoxicity, DNA Damage, and PCNA Alterations in Male Rats," Hindawi, pp. 1-11, 2018.

30. W.M.Iorjiim, "Moringa oleifera Leaf Extract Promotes Antioxidant, Survival,
Fecundity, and Locomotor Activities in Drosophila melanogaster," European J. Med. Plants, pp. 30-42, 2020.

How to cite this article: Fitri Suryani Hadi, Arni Amir, Desmiwarti et.al. The effect of moringa oleifera leaf water extract on the number of ovarian follicles and the enzyme levels of superoxide dismutase of rattus norvegicus rats exposed to depot medroxyprogesterone acetate (DMPA). International Journal of Science \& Healthcare Research. 2022; 7(1): 166-178. DOI: https://doi.org/10.52403/ijshr.20220128 